\title{
Detection of Representative Mutant Strains and a Case of Prolonged Infection by SARS-CoV-2 with Spike 69/70 Deletion in Japan
}

\author{
Kazuki Takano ${ }^{1,2}$ \\ Yuji Watanabe iD ${ }^{1,2}$ \\ Maya Hariu ${ }^{1,2}$ \\ Masafumi Seki (iD) \\ 'Division of Infectious Diseases and \\ Infection Control, ${ }^{2}$ Laboratory for \\ Clinical Microbiology, Tohoku Medical \\ and Pharmaceutical University Hospital, \\ Sendai City, Miyagi, Japan
}

\begin{abstract}
There is a concern that the spread of mutant strains of SARS-CoV-2 will increase the number of severe COVID-19 patients and weaken vaccine effectiveness in the world. The mutants of the spike region of SARS-CoV-2, such as N501Y, E484K, P681H, and deletion H69/V70 (del 69/70), were studied in 25 COVID-19 patients admitted from December 2020 to April 2021; there were no patients with N501Y and P681H, but nine patients had E484K alone. Their symptoms, laboratory data, and course of their disease were similar to those of the other patients with the non-mutant virus. One patient with del69/70 alone showed prolonged inflammation, viral excretion, and late exacerbation 18 days after onset. Del69/ 70 may be independently associated with evasion of immunity, as previously reported, and it is present in Japan.
\end{abstract}

Keywords: COVID-19, N501Y, E484K, P681H, PCR, remdesivir, vaccine

There has been a worldwide pandemic of coronavirus disease 2019 (COVID-19), including Japan, since February 2020, and the spread of mutant viral strains, such as $\mathrm{N} 501 \mathrm{Y}$ and $\mathrm{E} 484 \mathrm{~K}$, of the spike protein of SARS-CoV-2 has become a major issue. $^{1,2}$

N501Y was first reported from the United Kingdom as a representative mutant in the B1.1.7 lineage (now called Alpha variant), and it was suggested that it has increased infectivity. ${ }^{2,3}$ In the B1.1.7 lineage, $\mathrm{P} 681 \mathrm{H}$ and deletion of H69/V70 (del 69/70) were also reported to be resistant to the anti-viral agent remdesivir and to have an allosterically changed spike protein conformation, respectively. ${ }^{3-5}$ E484K was found in South Africa and Brazil with the N501Y mutant, and they appear to be associated with decreased vaccine efficacy. ${ }^{2} \mathrm{~N} 501 \mathrm{Y}$ and E484K are representative and well-known mutant, but $\mathrm{P} 681 \mathrm{H}$ and del69/70 are also important, because they could directly affect the treatment and pathophysiological features of the patients.

In Japan, it has been reported that the N501Y mutant and severe COVID-19 patients had increased rapidly in the western area, including the Osaka City area, and that the E484K alone mutant appeared in the eastern area, especially around the Tokyo Metropolitan area in April 2021. ${ }^{6}$ However, the prevalence of other mutants, such as $\mathrm{P} 681 \mathrm{H}$ and del69/70, is unknown.

Therefore, the prevalence of these mutants was analyzed in 25 COVID-19 patients admitted to our hospital located in Tohoku rural area from December 2020 to April 2021 by polymerase chain reaction (PCR)-based detection
Correspondence: Masafumi Seki

Division of Infectious Diseases and Infection Control, Tohoku Medical and

Pharmaceutical University Hospital, I-I2-I

Fukumuro, Miyagino-ku, Sendai City, Miyagi, 983-86I2, Japan

Tel $+8|-22-983-| 22 \mid$

Fax +8I-22-983-1232

Email m-seki@tohoku-mpu.ac.jp 
kits (VirSNiP-SAS B1351 $(484 \mathrm{~K}+501 \mathrm{Y})$, SARS-CoV-2 Spike P681Y, and del H69/N70, respectively; Roche, Basel, Switzerland).

Table 1 shows the results. There were no patients with $\mathrm{N} 501 \mathrm{Y}$ and $\mathrm{P} 681 \mathrm{H}$, though some patients showed severe disease and delayed improvement with administration of remdesivir. In contrast, nine patients had the E484K mutation without N501Y and other mutants. These nine patients had mild to severe disease and ranged in age from young to old; therefore, there were no common clinical features.

However, one patient was found to have del69/70 alone, and this young patient with no underlying diseases showed prolonged symptoms and late exacerbation over two weeks after onset despite appropriate treatment. His symptoms, including dyspnea and general fatigue, increased on Day 18. The physical examination findings were as follows: temperature $39.2^{\circ} \mathrm{C}$, blood pressure $110 / 72 \mathrm{mmHg}$, respiratory rate 24 breaths/ min, and $\mathrm{SpO}_{2} 94 \%$ on room air. His initial white blood cell (WBC) count was 13,500/uL. The C-reactive protein (CRP) value was $23.67 \mathrm{mg} / \mathrm{dL}$, and D-dimer was $3.57 \mathrm{mg} / \mathrm{dL}$. However, almost no pneumonia and abnormalities, including ground glass opacities, were found on imaging examinations (Figure 1A and B). In addition, no superinfecting bacteria and fungi were detected. He received remdesivir and dexamethasone from Day 1, and, fortunately, recovered rapidly. As previously reported, del69/70 mutant independently might lead to evasion of immunity and resulted in prolonged viral excretion.

It is important to be vigilant regarding the existence of mutant strains other than $\mathrm{N} 501 \mathrm{Y}$ and $\mathrm{E} 484 \mathrm{~K}$ if patients show delayed improvement despite receiving appropriate treatment in Japan and other areas where the mutants are not highly prevalent. This is a commentary from the single facility; therefore, we should plan the further region-wide investigations to detect the critical mutants associated with the pathogenesis of the COVID-19 in each area.

Table I Patients' Characteristics and Mutations Detected

\begin{tabular}{|c|c|c|c|c|c|c|c|c|c|c|}
\hline \multirow{2}{*}{$\begin{array}{l}\text { Patient } \\
\text { No. }\end{array}$} & \multirow{2}{*}{$\begin{array}{c}\text { Malel } \\
\text { Female }\end{array}$} & \multirow[t]{2}{*}{ Age } & \multirow[t]{2}{*}{ WBC } & \multirow{2}{*}{$\begin{array}{c}\text { CRP } \\
(\mathrm{mg} / \mathrm{dl})\end{array}$} & \multirow{2}{*}{$\begin{array}{l}\text { D-Dimer } \\
\text { (ug/mL) }\end{array}$} & \multirow{2}{*}{$\begin{array}{c}\text { Duration of } \\
\text { Symptoms (Days) }\end{array}$} & \multirow{2}{*}{$\begin{array}{c}\text { Mutation } \\
\text { del H69/ } \\
\text { V70 }\end{array}$} & \multirow[b]{2}{*}{ P68IH } & \multirow[b]{2}{*}{ E484K } & \multirow[b]{2}{*}{ N50IY } \\
\hline & & & & & & & & & & \\
\hline 1 & $\mathrm{~F}$ & 85 & 7200 & 1.15 & 0.88 & 5 & None & None & None & None \\
\hline 2 & $M$ & 71 & 12,800 & 2.42 & 7.91 & 4 & None & None & None & None \\
\hline 3 & $M$ & 86 & 11,700 & 7.53 & 1.64 & 5 & None & None & None & None \\
\hline 4 & $M$ & 74 & 6900 & 9.4 & 8.84 & 2 & None & None & None & None \\
\hline 5 & $\mathrm{~F}$ & 27 & 5900 & 0.02 & 0.51 & 4 & None & None & None & None \\
\hline 6 & $\mathrm{~F}$ & 50 & 8900 & 5.16 & 0.67 & 5 & None & None & None & None \\
\hline 7 & $\mathrm{~F}$ & 85 & 2400 & 3.84 & 0.83 & 4 & None & None & None & None \\
\hline 8 & $M$ & 64 & 4400 & 6.18 & 0.86 & 3 & None & None & None & None \\
\hline 9 & $M$ & 74 & 7300 & 0.71 & 1.41 & 2 & None & None & None & None \\
\hline 10 & $\mathrm{~F}$ & 81 & 2700 & 0.94 & 0.96 & 3 & None & None & None & None \\
\hline 11 & $M$ & 86 & 4400 & 7.79 & 2.19 & 3 & None & None & None & None \\
\hline 12 & $\mathrm{~F}$ & 25 & 4900 & 0.18 & 1.2 & 7 & None & None & Positive & None \\
\hline 13 & $M$ & 77 & 7800 & 2.12 & 2.67 & 4 & None & None & Positive & None \\
\hline 14 & $\mathrm{~F}$ & 67 & 3100 & 1.15 & 0.57 & 4 & None & None & Positive & None \\
\hline 15 & $M$ & 72 & 6000 & 0.29 & 8.41 & 3 & None & None & None & None \\
\hline 16 & $\mathrm{~F}$ & 75 & 3500 & 8.97 & 1.3 & 7 & None & None & Positive & None \\
\hline 17 & $M$ & 65 & 10,500 & 6.89 & 1.43 & 2 & None & None & Positive & None \\
\hline 18 & $M$ & 76 & 8600 & 12.01 & 1.68 & 3 & None & None & Positive & None \\
\hline 19 & $M$ & 87 & 5100 & 5.34 & 2.53 & 3 & None & None & Positive & None \\
\hline 20 & $M$ & 46 & 4700 & 0.02 & 0.12 & 2 & None & None & Positive & None \\
\hline 21 & $M$ & 68 & 5700 & 0.32 & 1.35 & 2 & None & None & Positive & None \\
\hline 22 & $M$ & 88 & 4800 & 0.38 & 0.96 & 2 & None & None & None & None \\
\hline 23 & $M$ & 79 & 3000 & 4.68 & 1.57 & 9 & None & None & None & None \\
\hline 24 & $\mathrm{~F}$ & 51 & 5900 & 3.2 & 1.34 & 5 & None & None & None & None \\
\hline 25 & $M$ & 39 & 13,400 & 25.94 & 3.37 & 18 & Positive & None & None & None \\
\hline
\end{tabular}

Abbreviations: M, male; F, female; WBC, white blood cells; CRP, C-reactive protein. 

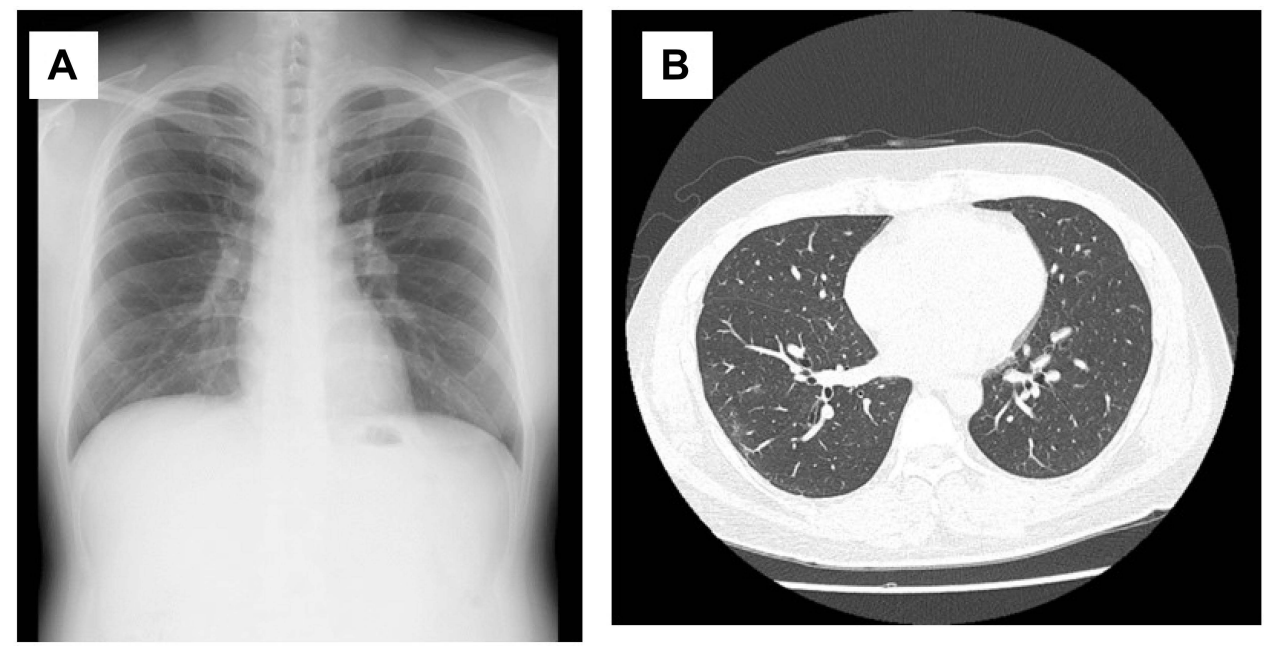

Figure I The chest X-ray (A) and computed tomography (CT) (B) findings of a 39-year-old COVID-19 patient. Almost no abnormal findings, including ground glass opacities (GGOs), are seen.

\section{Ethics}

The analysis was approved by the Committee for Clinical Scientific Research of Tohoku Medical and Pharmaceutical University Hospital on April 7, 2021 and July 14, 2021 (No. ID 2020-6-006 and 2021-2-032), respectively, and the patients provided written, informed consent for use of their specimens, although the samples were collected as part of routine laboratory analyses. The patient with del 69/70 was also provided written informed consent for the his cases details to be published.

\section{Disclosure}

The authors report no conflicts of interest in this work.

\section{References}

1. Seki M. Trends in the management of infectious disease under SARS-CoV-2 era: from pathophysiological comparison of COVID-19 and influenza. World $J$ Virol. 2021;10:62-68. doi:10.5501/wjv.v10.i2.62
2. Kuzmina A, Khalaila Y, Voloshin O, et al. SARS-CoV-2 spike variants exhibit differential infectivity and neutralization resistance to convalescent or post-vaccination sera. Cell Host Microbe. 2021;29:522-528. doi:10.1016/j.chom.2021.03.008

3. Rambaut A, Loman N, Pybus O, et al. Preliminary genomic characterisation of an emergent SARS-CoV-2 lineage in the UK defined by a novel set of spike mutations. ARTIC Network 2020; Available from: https://virological.org/t/preliminary-genomic-characterisationof-an-emergent-sars-cov-2-lineage-in-the-uk-defined-by-a-novel-setof-spike-mutations/563. Accessed June 26, 2021.

4. Lubinski B, Tang T, Daniel S, Jaimes JA, Whittaker GR. Functional evaluation of proteolytic activation for the SARS-CoV-2 variant B.1.1.7: role of the P681H mutation. bioRxiv. 2021. doi:10.1101/ 2021.04.06.438731.

5. Kemp SA, Collier DA, Datir RP, et al. SARS-CoV-2 evolution during treatment of chronic infection. Nature. 2021;592:277-282. doi:10.1038/s41586-021-03291-y

6. Hirotsu Y, Omata M. Discovery of a SARS-CoV-2 variant 1 from the P.1 lineage harboring $\mathrm{K} 417 \mathrm{~T} / \mathrm{E} 484 \mathrm{~K} / \mathrm{N} 501 \mathrm{Y}$ mutations in Kofu, Japan. J Infect. 2021. doi:10.1016/j.jinf.2021.03.013.

\section{Publish your work in this journal}

Infection and Drug Resistance is an international, peer-reviewed openaccess journal that focuses on the optimal treatment of infection (bacterial, fungal and viral) and the development and institution of preventive strategies to minimize the development and spread of resistance. The journal is specifically concerned with the epidemiology of antibiotic resistance and the mechanisms of resistance development and diffusion in both hospitals and the community. The manuscript management system is completely online and includes a very quick and fair peerreview system, which is all easy to use. Visit http://www.dovepress.com/ testimonials.php to read real quotes from published authors. 